\title{
OPTIMASI TEKNIK ISOLASI RNA DAUN DAN AKAR BIBIT KELAPA SAWIT (Elaeis guineensis Jacq.)
}

\section{Optimization of RNA Isolation Techniques from Leaves and Roots of Oil Palm Seedlings (Elaeis guineensis Jacq.)}

\author{
Dini Astika Sari ${ }^{1 *}$, Irfan Martiansyah ${ }^{1}$, Restu Prasetya Mukmin ${ }^{2}$, Sapto Nugroho Hadi ${ }^{2}$, Indra \\ Syahputra ${ }^{4}$, Dadang Afandi ${ }^{4}$, dan Riza-Arief Putranto ${ }^{1,3, *}$ \\ 1) Pusat Penelitian Bioteknologi dan Bioindustri Indonesia (PPBBI). \\ Jl. Taman Kencana No. 1 Bogor 16128; \\ 2) Fakultas Pertanian Universitas Jenderal Soedirman Purwokerto. \\ Jl. DR. Soeparno, Purwokerto Utara 53122; \\ 3) PT Riset Perkebunan Nusantara, Jl. Salak No 1A, Bogor 16128 \\ ${ }^{4)}$ PT Socfin Indonesia, Jl. KL Yos Sudarso No. 106, medan 20115, Sumatera Utara.
}

Alamat Korespondensi:*dini.astika@gmail.com; rizaputranto@iribb.org

\begin{abstract}
ABSTRAK
Tanaman kelapa sawit memiliki kandungan polisakarida dan polifenol yang tinggi sehingga menyebabkan hasil isolasi RNA memiliki kualitas dan kuantitas yang rendah. Penelitian ini dilakukan untuk mengoptimasi beberapa protokol isolasi RNA tanaman kelapa sawit untuk meningkatkan efektivitas, efisiensi, serta kualitas dan kuantitas. Penelitian dilakukan dengan melaksanakan teknik isolasi RNA berbasis manual dan kit komersial, yang terbagi atas tiga protokol uji, yaitu: 1) protokol manual modifikasi Cetyl Trimethyl Ammonium Bromide (CTAB), 2) protokol kit isolasi RNA \#1 berbasis buffer RLT yang mengandung guanidin thiosianat, dan 3) protokol kit isolasi $R N A \# 2$ berbasis buffer RAP yang mengandung guanidin hidroklorida. Sampel yang digunakan adalah daun dan akar dari bibit kelapa sawit yang ditanam dalam pembibitan terkendali, serta berumur kurang dari tiga bulan dengan bobot 0,1 gram dan 2,5 gram yang disesuaikan untuk tiap protokol. Variabel yang diamati adalah parameter kuantitatif, yakni: konsentrasi (ng/ $\mu \mathrm{l}$ ), kemurnian (rasio $\mathrm{A}_{260} / \mathrm{A}_{280}$ dan $\mathrm{A}_{260} / \mathrm{A}_{230}$ ), serta parameter kualitatif, yakni: pita RNA pada elektroforesis gel agarosa. Hasil penelitian menunjukkan bahwa secara kuantitatif, RNA total hasil isolasi protokol kit isolasi RNA \#2 memiliki hasil paling tinggi. Konsentrasi RNA total daun dan akar kelapa sawit yang didapatkan melalui protokol kit isolasi RNA \#2 sebesar $338 \mathrm{ng} / \mu 1$ dan 184,4 ng/ $\mu 1$ dengan rasio $\mathrm{A}_{260} / \mathrm{A}_{280}$ RNA total daun dan akar kelapa sawit sebesar 2,13 dan 2,18 serta rasio $\mathrm{A}_{260} / \mathrm{A}_{230}$ sebesar 2,09 dan 2,20. Hasil analisis kualitatif RNA berbasis elektroforesis gel agarosa menunjukkan bahwa protokol kit baik kit \#1 dan \#2 memiliki profil integritas yang lebih baik dibandingkan protokol manual.
\end{abstract}

Kata kunci: kelapa sawit, optimasi, isolasi RNA, kit, manual

\section{ABSTRACT}

Oil palm contains high levels of polysaccharides and polyphenols causing the low quality and quantity of extracted RNA. The aim of this study was to optimize RNA isolation protocols from oil palm tissues referred to $R N A$ quantitative and qualitative analyses. The research was carried out by performing both of manual and commercial kit techniques, and consisted of three main protocols, e.g: 1) modified-manual protocols of Cetyl Trimethyl Ammonium Bromide (CTAB), 2) commercial RNA kit protocol \#1 with RLT buffer contains guanidine thyocyanate, and 3) commercial RNA kit protocol \#2 with RAP buffer contains guanidine hydrochloride. The leaves and roots of 3-months-old seedlings in controlled nursery were used and weighted in a range of 0,1 gram and 2,5 gram which was adjusted for each protocol. The analysis was carried out by performing quantitative and qualitative analyses. Quantitative parameters, e.g: $R N A$ concentration $(n g / \mu l), R N A$ purity $\left(A_{260} / A_{280}\right.$ and $A_{260} / A_{230}$ ratio) and quality parameter of RNA by the electrophoresis gel agarose were observed. The result showed that total RNA yield from the commercial RNA kit protocol \#2 performed the highest quality. Total RNA concentration of leaves and roots obtained from commercial RNA kit protocol \#2 was $338 \mathrm{ng} / \mu \mathrm{l}$ and $184,4 \mathrm{ng} / \mu \mathrm{l}$ with $A_{260} / A_{280}$ ratio of leaves and roots of oil palm total $R N A$ was 2,13 and 2,1 also $A_{260} / A_{230}$ ratio was 2,09 and 2,20 respectively. The result of agarose electrophoresis gel indicated both of the commercial RNA kit protocols performed higher integrity profile compared to manual protocol.

Keywords: oil palm, optimization, RNA isolation, kit, manual. 


\section{PENDAHULUAN}

Ketersediaan RNA dengan kualitas tinggi merupakan syarat penting dalam beberapa analisis transkriptomika, seperti studi perbandingan ekspresi gen $[D G E$ (Differential Gene Expression)] ataupun sekuensing RNA [RNA-sequencing] (Liu et al., 2005; Wang et al., 2008). Namun demikian, sangat sulit untuk mendapatkan RNA total dengan kualitas dan kuantitas tinggi terutama dari jaringan tanaman yang banyak mengandung komponen polisakarida dan polifenol. Sampel yang terkontaminasi oleh polisakarida dan polifenol akan menyebabkan RNA terdegradasi dan menurunkan kualitas serta kuantitas RNA. Isolasi RNA merupakan proses penting dengan tahapan yang cukup panjang dan rumit, serta menggunakan bahan kimia spesifik seperti fenol dan kloroform (Xiao et al., 2012). Menurut Suehiro et al. (2005), tahapan yang panjang dalam proses isolasi RNA juga sekaligus menyebabkan kemungkinan terjadinya tingkat kontaminasi yang tinggi, sehingga hasil RNA total yang diperoleh tidak sesuai. Hal tersebut mendorong banyak peneliti untuk mengembangkan protokol baru untuk isolasi RNA dari beberapa jaringan tanaman yang sulit, seperti memiliki kandungan polisakarida dan polifenol yang tinggi (Gasic et al., 2004; Iandolino et al., 2004).
Hingga saat ini, beberapa penelitian transkriptomika pada tanaman kelapa sawit masih mengalami kendala dalam proses isolasi RNA. Penelitian ini dilakukan untuk mengoptimasi beberapa protokol isolasi RNA terkhusus untuk bibit tanaman kelapa sawit yang efektif dan efisien, serta menghasilkan RNA yang berkualitas tinggi dari segi kualitas maupun kuantitas. Protokol isolasi RNA yang diteliti berbasis manual dan kit komersial. Hal ini dikarenakan metode manual memiliki proses yang lebih panjang namun menunjukkan hasil yang lebih baik, sedangkat metode kit memiliki protokol yang lebih sederhana dan cepat, namun pada beberapa sampel menunjukkan hasil dengan kuantitas yang lebih rendah. Pada penelitian ini, dilakukan uji perbandingan dan optimasi antara protokol isolasi RNA manual yakni protokol Cetyl Trimethyl Ammonium Bromide (CTAB) (Chang et al., 1993) yang dimodifikasi, dengan protokol isolasi RNA berbasis kit \#1 dan kit \#2 terhadap sampel daun dan akar bibit kelapa sawit. Hasil optimasi isolasi RNA terbaik yang didapatkan dalam penelitian ini diharapkan mampu menjadi acuan pelaksanaan isolasi RNA pada tanaman kelapa sawit.

\section{METODE PENELITIAN}

Penelitian ini dilaksanakan dengan menggunakan bahan yaitu buffer ekstraksi 
CTAB yang dimodifikasi dan terdiri atas CTAB 2\%, PVP 2\%, Tris HCl $100 \mathrm{mM} \mathrm{pH}$ 8, EDTA $25 \mathrm{mM}, \quad \mathrm{NaCl} 2 \mathrm{M}, \quad \beta-$ mercaptoethanol 2\%, Chloroform: Isoamyl alcohol (24:1), Phenol: Chloroform: Isoamyl alcohol (25:24:1), $\mathrm{LiCl} 10 \mathrm{M}$, buffer SSTE yang terdiri atas $\mathrm{NaCl} 1 \mathrm{M}$, SDS 0,5\%, Tris $\mathrm{HCl} 10 \mathrm{mM}$ pH 8, EDTA 1 $\mathrm{mM} \mathrm{pH} 8$, serta kit isolasi RNA komersial \#1 dan \#2. Alat yang digunakan antara lain tube (Thermo Scientific), waterbath (Memmert), spektrofotometer Nanodrop 2000 (Thermo Scientific), dan UV transilluminator.

Penelitian dilaksanakan di Laboratorium Biokimia dan Biologi Molekuler, Pusat Penelitian Bioteknologi dan Bioindustri Indonesia (PPBBI) Bogor, Jawa Barat. Penelitian dilaksanakan selama tiga (3) bulan dimulai dari bulan Oktober sampai dengan Desember 2018.

Bahan tanaman yang digunakan dalam penelitian ini adalah organ akar dan daun bibit tanaman kelapa sawit berumur kurang dari tiga bulan dari pembibitan terkontrol milik PT Socfindo, Tanah Gambus, Medan.

Penelitian dilakukan dengan melaksanakan teknik isolasi RNA berbasis manual dan kit komersial, menggunakan tiga protokol uji yakni: 1) manual CTAB modifikasi mengacu pada penelitian terdahulu oleh Martiansyah et al., 2018, 2) kit isolasi RNA \#1 berbasis buffer RLT yang mengandung guanidin thiosianat, dan 3) protokol kit isolasi $R N A$ \#2 berbasis buffer RAP yang mengandung guanidin hidroklorida. Bahan berupa organ akar dan daun yang akan diisolasi memiliki bobot sampel 2,5 gram untuk teknik isolasi manual dan 0,1 gram untuk teknik isolasi kit komersial \#1 dan \#2. Variabel yang diamati adalah parameter kuantitatif, yakni: konsentrasi $(\mathrm{ng} / \mu \mathrm{l})$, kemurnian $\left(\mathrm{A}_{260} / \mathrm{A}_{280}\right.$ dan $\left.A_{260} / A_{230}\right)$ serta parameter kualitatif berdasarkan pita RNA pada elektroforesis gel agarosa. Kuantitas RNA total diperiksa menggunakan mesin spektrofotometer Nanodrop 2000 (Thermo Scientific). Kualitas RNA total ditentukan menggunakan prosedur elektroforesis gel agarosa 1,2\% berdasarkan profil pita ganda $18 \mathrm{~S}$ rRNA dan $28 \mathrm{~S}$ rRNA.

\section{HASIL DAN PEMBAHASAN}

\section{Uji Kuantitatif RNA dengan Spektrofotometer}

Hasil uji kuantitatif RNA total dengan menggunakan protokol manual CTAB modifikasi disajikan pada Tabel 1. Isolasi RNA total tanaman kelapa sawit menggunakan protokol manual CTAB modifikasi menghasilkan 17 tabung berisi RNA total dari sampel daun kelapa sawit dan 15 tabung berisi RNA total dari sampel akar kelapa sawit. 
Tabel 1. Hasil uji kuantitas dan kualitas RNA total protokol manual CTAB modifikasi

\begin{tabular}{|c|c|c|c|}
\hline Sampel & Konsentrasi $(\mathrm{ng} / \mu \mathrm{l})$ & $\mathrm{A}_{260} / \mathrm{A}_{280}$ & $\mathrm{~A}_{260} / \mathrm{A}_{230}$ \\
\hline Daun 1 & 55,30 & 1,80 & 1,13 \\
\hline Daun 2 & 101,80 & 1,69 & 0,87 \\
\hline Daun 3 & 163,20 & 1,58 & 0,85 \\
\hline Daun 4 & 71,20 & 1,52 & 0,81 \\
\hline Daun 5 & 71,30 & 1,66 & 0,82 \\
\hline Daun 6 & 166,70 & 1,63 & 0,69 \\
\hline Daun 7 & 225,40 & 1,70 & 0,89 \\
\hline Daun 8 & 202,60 & 1,67 & 0,81 \\
\hline Daun 9 & 35,20 & 1,64 & 0,71 \\
\hline Daun 10 & 127,70 & 1,86 & 1,68 \\
\hline Daun 11 & 323,60 & 1,94 & 2,04 \\
\hline Daun 12 & 43,20 & 1,82 & 1,56 \\
\hline Daun 13 & 112,00 & 1,88 & 1,98 \\
\hline Daun 14 & 30,90 & 1,79 & 1,62 \\
\hline Daun 15 & 34,60 & 1,74 & 1,26 \\
\hline Daun 16 & 23,80 & 1,67 & 1,08 \\
\hline Daun 17 & 50,00 & 1,87 & 1,75 \\
\hline Akar 1 & 140,70 & 1,91 & 1,75 \\
\hline Akar 2 & 112,40 & 1,92 & 1,79 \\
\hline Akar 3 & 71,70 & 1,92 & 1,65 \\
\hline Akar 4 & 345,10 & 1,95 & 1,99 \\
\hline Akar 5 & 485,90 & 1,87 & 2,02 \\
\hline Akar 6 & 83,60 & 1,93 & 1,32 \\
\hline Akar 7 & 217,10 & 1,94 & 1,87 \\
\hline Akar 8 & 344,40 & 1,91 & 1,99 \\
\hline Akar 9 & 121,10 & 1,83 & 1,85 \\
\hline Akar 10 & 2650,10 & 1,90 & 2,13 \\
\hline Akar 11 & 26,00 & 2,02 & 1,51 \\
\hline Akar 12 & 76,50 & 1,80 & 1,54 \\
\hline Akar 13 & 177,20 & 1,82 & 1,83 \\
\hline Akar 14 & 204,10 & 1,86 & 1,64 \\
\hline Akar 15 & 185,70 & 1,81 & 1,93 \\
\hline
\end{tabular}

Isolasi RNA total tanaman kelapa sawit menggunakan protokol manual CTAB modifikasi menghasilkan 17 tabung berisi RNA total dari sampel daun kelapa sawit dan 15 tabung berisi RNA total dari sampel akar kelapa sawit. Hasil pengujian RNA total protokol manual CTAB modifikasi menunjukkan bahwa konsentrasi RNA total daun kelapa sawit yang didapatkan menunjukkan hasil bervariasi dan berkisar pada konsentrasi 23,8-323,6 $\mathrm{ng} / \mu \mathrm{l}$ dengan rentang rasio $\mathrm{A}_{260} / \mathrm{A}_{280}$ 1,52-1,94 dan rentang rasio $\mathrm{A}_{260} / \mathrm{A}_{230}$ 0,71-2,04. Konsentrasi RNA total akar kelapa sawit yang didapatkan menunjukkan hasil bervariasi dan berkisar pada konsentrasi 26,0-485,9 ng/ $\mu$ l dengan rentang rasio $\mathrm{A}_{260} / \mathrm{A}_{280} \quad 1,80-2,02$ dan rentang rasio $\mathrm{A}_{260} / \mathrm{A}_{230} \quad 1,26-2,13$. Berdasarkan hasil tersebut diketahui bahwa 
RNA total daun kelapa sawit dengan profil kuantitas terbaik adalah sampel daun 11 yakni menunjukkan konsentrasi sebesar $323,6 \mathrm{ng} / \mu \mathrm{l}$; rasio $\mathrm{A}_{260} / \mathrm{A}_{280}$ 1,94; dan rasio $\mathrm{A}_{260} / \mathrm{A}_{23} 2,04$. RNA total akar kelapa sawit dengan profil kuantitas terbaik adalah sampel akar 10 yakni menunjukkan konsentrasi sebesar 2650,1 ng/ $\mu \mathrm{l}$; rasio $\mathrm{A}_{260} / \mathrm{A}_{280}$ 1,90; dan rasio $\mathrm{A}_{260} / \mathrm{A}_{230} 2,13$.

Nilai rasio $\mathrm{A}_{260} / \mathrm{A}_{280} \mathrm{RNA}$ total daun dan akar kelapa sawit hasil isolasi protokol manual CTAB modifikasi yang kurang dari 1,80 menunjukkan adanya kontaminasi protein. Gallagher (1989) menyatakan bahwa, nilai rasio $\mathrm{A}_{260} / \mathrm{A}_{280}$ yang kurang dari 1,80 untuk RNA mengindikasikan adanya kontaminan protein dan fenol yang diserap kuat pada panjang gelombang 280 $\mathrm{nm}$, serta DNA yang diserap kuat pada panjang gelombang $260 \mathrm{~nm}$. Nilai rasio $\mathrm{A}_{260} / \mathrm{A}_{230}$ RNA total daun dan akar kelapa sawit hasil isolasi protokol manual CTAB modifikasi yang kurang dari 1,80 menunjukkan adanya kontaminasi polisakarida dan residu organik lain. Menurut Rapley dan Heptinstall (1998), polisakarida terserap kuat pada panjang gelombang $230 \mathrm{~nm}$, sedangkan menurut Teare et al. (1997) absorbansi tinggi pada panjang gelombang $230 \quad \mathrm{~nm}$ mengindikasikan adanya garam buffer, pelarut dan kontaminan lain. Menurut Sambrook et al. (1989), protokol manual tidak cukup sensitif dan tidak spesifik untuk untai tunggal RNA, serta rentan terpengaruh oleh adanya kontaminan pada sampel.

Hasil uji kuantitatif RNA total dari sampel daun dan akar kelapa sawit dengan protokol kit komersial \#1 disajikan pada Tabel 2.

Profil parameter kuantitatif RNA hasil isolasi menggunakan protokol kit komersial \#1 menunjukkan konsentrasi RNA total daun kelapa sawit sebesar 85,4 $\mathrm{ng} / \mu \mathrm{l}$; rasio $\mathrm{A}_{260} / \mathrm{A}_{280}$ sebesar 2,11 ; dan rasio $\mathrm{A}_{260} / \mathrm{A}_{230}$ sebesar 1,69, sedangkan RNA total akar kelapa sawit yang didapatkan menunjukkan konsentrasi sebesar 67,8 ng/ $\mu \mathrm{l}$; rasio $\mathrm{A}_{260} / \mathrm{A}_{280}$ sebesar 2,19; dan rasio $\mathrm{A}_{260} / \mathrm{A}_{230}$ sebesar 1,34.

Nilai rasio $\mathrm{A}_{260} / \mathrm{A}_{280} \mathrm{RNA}$ total daun dan akar kelapa sawit hasil isolasi protokol kit komersial \#1 yang lebih dari 2,0 menunjukkan RNA total yang murni, sedangkan nilai rasio $\mathrm{A}_{260} / \mathrm{A}_{230} \mathrm{RNA}$ total daun dan akar kelapa sawit yang kurang dari 1,80 menunjukkan adanya kontaminasi polisakarida. Nilai rasio $\mathrm{A}_{260} / \mathrm{A}_{280} \mathrm{RNA}$ total daun dan akar kelapa sawit yang lebih dari 2,0 menunjukkan bahwa RNA total tersebut murni dan tidak terkontaminasi oleh protein, fenol, maupun DNA genom. Hal tersebut dikarenakan protokol kit komersial \#1 menggunakan buffer RLT yang mengandung guanidin thiosianat. Farrel (2005) menyebutkan bahwa, guanidin thiosianat mampu mendenaturasi 
Tabel 2. Hasil uji kuantitatif RNA total dengan protokol kit komersial \#1

\begin{tabular}{lccc}
\hline Sampel & Konsentrasi $(\mathrm{ng} / \mu \mathrm{l})$ & $\mathrm{A}_{260} / \mathrm{A}_{280}$ & $\mathrm{~A}_{260} / \mathrm{A}_{230}$ \\
\hline Daun & 85,40 & 2,11 & 1,69 \\
Akar & 67,80 & 2,19 & 1,34 \\
\hline
\end{tabular}

Tabel 3. Hasil uji kuantitatif RNA total protokol kit komersial \#2

\begin{tabular}{lccc}
\hline Sampel & Konsentrasi $(\mathrm{ng} / \mu \mathrm{l})$ & $\mathrm{A}_{260} / \mathrm{A}_{280}$ & $\mathrm{~A}_{260} / \mathrm{A}_{230}$ \\
\hline Daun & 338,00 & 2,13 & 2,09 \\
Akar & 184,40 & 2,18 & 2,20 \\
\hline
\end{tabular}

protein dan merubah struktur tersier molekul RNase sehingga menghambat daya rusak protein terhadap RNA. Selain itu menurut Qiagen (2006), guanidin thiosianat yang terkandung dalam buffer RLT berfungsi untuk menonaktifkan enzim RNase sehingga menghasilkan isolat RNA utuh (tidak terdegradasi) dan mampu menghancurkan serta melarutkan sel dengan cepat sehingga membuat RNA memiliki nilai kelarutan yang lebih tinggi.

Hasil uji kuantitatif RNA total dari sampel daun dan akar kelapa sawit protokol kit komersial \#2 disajikan pada Tabel 3. Profil parameter kuantitatif RNA hasil isolasi menggunakan protokol kit komersial \#2 menunjukkan konsentrasi RNA total daun kelapa sawit sebesar $338 \mathrm{ng} / \mu 1$; rasio $\mathrm{A}_{260} / \mathrm{A}_{280}$ sebesar 2,13; dan rasio $\mathrm{A}_{260} / \mathrm{A}_{230}$ sebesar 2,09, sedangkan RNA total akar kelapa sawit yang didapatkan menunjukkan konsentrasi sebesar 184,4 ng/ $\mu$; rasio $\mathrm{A}_{260} / \mathrm{A}_{280}$ sebesar 2,18; dan rasio $\mathrm{A}_{260} / \mathrm{A}_{230}$ sebesar 2,20.

Nilai rasio $\mathrm{A}_{260} / \mathrm{A}_{280} \mathrm{RNA}$ total daun dan akar kelapa sawit yang lebih dari 2,0 menunjukkan bahwa RNA total tersebut murni dan tidak terkontaminasi oleh protein, fenol, maupun DNA genom sedangkan nilai rasio $\mathrm{A}_{260} / \mathrm{A}_{230} \mathrm{RNA}$ total daun dan akar kelapa sawit yang lebih dari 2,0 menunjukkan bahwa RNA total tersebut murni dan tidak terkontaminasi oleh polisakarida. RNA total tersebut diekstraksi menggunakan buffer RAP yang mengandung guanidin hidroklorida yang disediakan oleh kit komersial \#2. Qiagen (2006) menjelaskan, guanidin hidroklorida memiliki kemampuan denaturasi dan homogenisasi sel yang lebih rendah dibandingkan dengan guanidin thiosianat. Namun, hasil yang didapat dari penelitian ini menunjukkan bahwa guanidin hidroklorida yang terkandung dalam buffer RAP menghasilkan RNA total berkualitas tinggi. Hal tersebut dikarenakan menurut Macherey-Nagel (2006), kit komersial \#2 didesain khusus untuk mendapatkan RNA berkualitas tinggi dan efektif untuk menghilangkan kontaminasi DNA selama proses purifikasi pada sampel tanaman dan jamur. Kit komersial \#2 dilengkapi dengan spin column yang mengandung DNase sehingga sangat sensitif untuk mendeteksi 
dan mereduksi adanya kontaminan DNA pada RNA.

Berdasarkan hasil uji kuantitas RNA total dari tiga protokol yang diuji mengindikasikan bahwa, RNA total hasil isolasi protokol kit komersial \#2 memberikan hasil RNA total dengan profil parameter kuantitas terbaik dibandingkan dengan RNA total hasil isolasi protokol manual Cetyl Trimethyl Ammonium Bromide (CTAB) (Chang et al., 1993) modifikasi maupun kit komersial \#1.

\section{Uji Kualitatif RNA dengan Elektroforesis Gel Agarosa}

Pengujian parameter kualitatif RNA dapat dilakukan dengan metode elektroforesis gel agarosa. Hasil elektroforesis RNA total yang menunjukkan standar kualitas baik menunjukkan dua buah pita (Gambar 1 dan Gambar 2). Rapley dan Heptinstall (1998) menjelaskan dua pita tersebut merupakan
RNA ribosomal (rRNA), yaitu 18S rRNA dan 28S rRNA yang merupakan komponen terbanyak dalam RNA total.

Mengacu kepada profil konsentrasi RNA total daun kelapa sawit pada Tabel 2, konsentrasi RNA total sumuran a adalah $225,4 \mathrm{ng} / \mu 1$, sumuran $\mathrm{b}$ adalah $43,2 \mathrm{ng} / \mu 1$, sumuran c adalah $85,4 \mathrm{ng} / \mu 1$ dan sumuran $\mathrm{d}$ adalah $338 \mathrm{ng} / \mu \mathrm{l}$. RNA total daun kelapa sawit yang di-running pada masing-masing sumuran dari a-d secara berurutan adalah sebanyak $1,1 \mu \mathrm{l} ; 5,7 \mu 1 ; 2,9 \mu 1$ dan $1 \mu 1$.

Mengacu kepada profil konsentrasi RNA total daun kelapa sawit pada Tabel 2, konsentrasi RNA total pada lajur a adalah $485,9 \mathrm{ng} / \mu 1$, lajur b adalah $177,2 \mathrm{ng} / \mu 1$, lajur c adalah $67,8 \mathrm{ng} / \mu 1$ dan lajur d adalah 184,4 $\mathrm{ng} / \mu 1$. RNA total akar kelapa sawit yang dirunning pada masing-masing sumuran dari a-d secara berurutan adalah sebanyak $1 \mu$; $1,4 \mu 1 ; 3,6 \mu 1$ dan $1,3 \mu 1$.

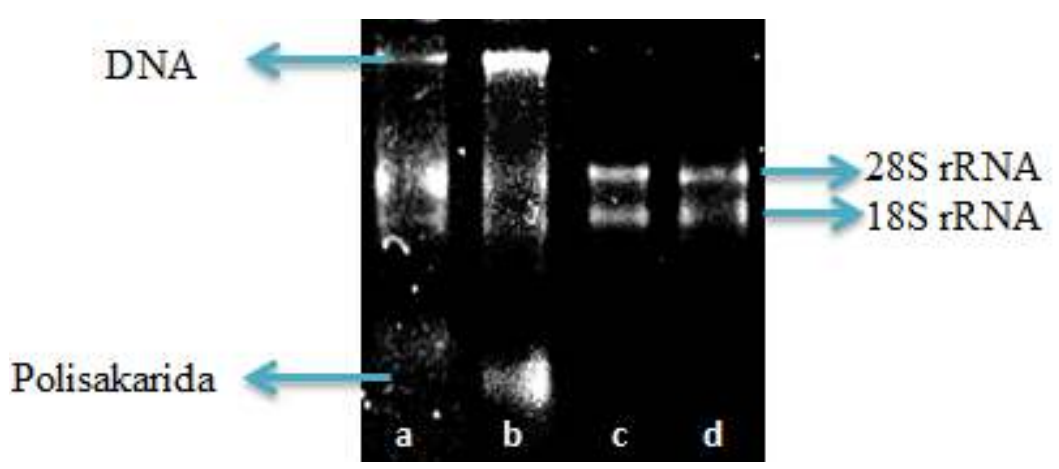

Gambar 1. Hasil elektroforesis RNA total daun kelapa sawit: (a) protokol CTAB modifikasi-1; (b) protokol CTAB modifikasi-2; (c) protokol kit komersial \#1; (d) protokol kit komersial \#2. 


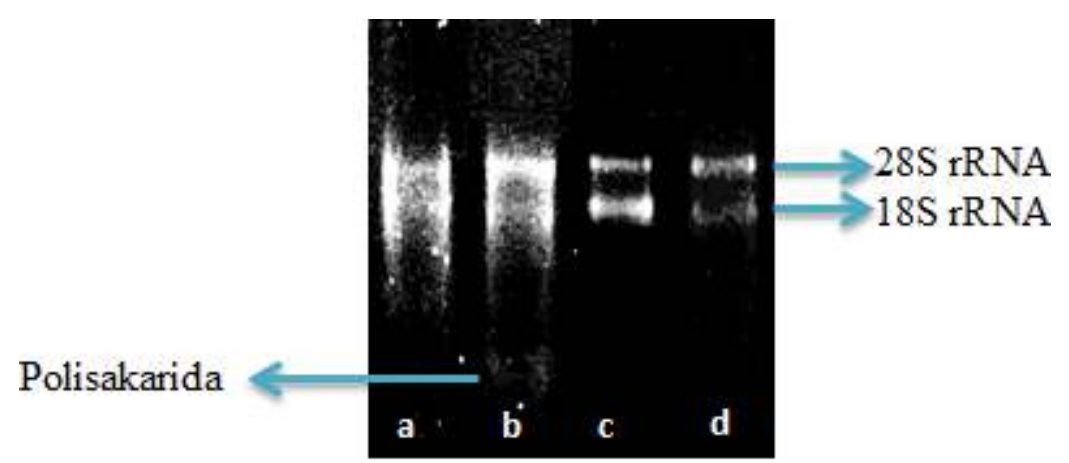

Gambar 2. Hasil elektroforesis RNA total akar kelapa sawit: (a) protokol CTAB modifikasi-1; (b) protokol CTAB modifikasi-2; (c) protokol kit komersial \#1; (d) protokol kit komersial \#2.

Jumlah RNA total yang di-running dihitung dengan rumus $\frac{250 \mathrm{ng}}{\text { konsentrasing/ } \mathrm{\mu l}}$ sehingga akan berbeda-beda berdasarkan konsentrasi masing-masing RNA total. Rumus tersebut digunakan karena rata-rata konsentrasi RNA total daun dan akar kelapa sawit yang didapat pada penelitian ini kurang dari $250 \mathrm{ng} / \mu 1$.

Hasil uji kualitas RNA menggunakan elektroforesis gel agarosa 1,2\% menunjukkan bahwa pada visualisasi elektroforegram RNA total daun kelapa sawit masih terdapat kontaminasi protein atau DNA dan polisakarida pada sumuran a dan $b$ yang merupakan RNA total hasil isolasi protokol manual CTAB modifikasi, namun tidak dijumpai kontaminasi protein/DNA dan polisakarida pada sumuran $\mathrm{c}$ dan $\mathrm{d}$ yang merupakan RNA total hasil isolasi protokol kit komersial \#1 dan protokol kit komersial \#2 (Gambar 1). Elektroforegram RNA total akar kelapa sawit menunjukkan bahwa masih terdapat kontaminasi polisakarida pada sumuran $b$ yang merupakan RNA total hasil isolasi protokol manual CTAB modifikasi-2 (ulangan 2), namun tidak dijumpai kontaminasi protein/DNA dan polisakarida pada sumuran a, c dan d yang merupakan RNA total hasil isolasi protokol manual CTAB modifikasi-1 (ulangan 1), kit komersial \#1 dan protokol kit komersial \#2 (Gambar 2).

Kontaminasi yang terjadi pada RNA total daun dan akar kelapa sawit hasil isolasi protokol manual CTAB modifikasi dikarenakan protokol manual memiliki kelemahan yakni tidak cukup sensitif dan tidak spesifik untuk untai tunggal RNA (Sambrook et al., 1989), sehingga memungkinkan terdapatnya kontaminan pada sampel selama proses isolasi. Penggunaan buffer guanidin thiosianat dan buffer guanidin hidroklorida dengan kemampuan denaturasi protein tinggi pada kit komersial \#1 dan protokol kit komersial \#2 menghasilkan profil elektroforegram 
yang mengindikasikan tidak adanya kontaminasi protein.

Elektroforegram RNA total daun dan akar kelapa sawit dari protokol manual CTAB modifikasi menunjukkan adanya smear. Menurut Xiao et al. (2012), protokol manual CTAB merupakan protokol isolasi RNA yang membutuhkan durasi dan tahapan panjang sehingga meningkatkan resiko terjadinya degradasi RNA selama proses isolasi. Xiao et al. (2012) dan Tattersall et al. (2005) juga menyebutkan bahwa, protokol isolasi manual RNA seperti CTAB tidak cocok digunakan untuk mengisolasi RNA dari jaringan tanaman berfamili Arecaceae karena tingginya kandungan polisakarida dan polifenolik pada bagian membran sel, sehingga menyebabkan terjadinya degradasi RNA dan kontaminasi DNA.

Smear tipis RNA total akar hasil isolasi protokol manual CTAB modifikasi menunjukkan adanya komponen RNA yang lain seperti, mRNA dan tRNA. Farrell (2005) menjelaskan, komponen mRNA dan tRNA ada dalam jumlah yang sangat sedikit sehingga terlihat sebagai smear tipis di bawah pita $18 \mathrm{~S}$ rRNA sampai mendekati bagian akhir gel. Menurut Bryant \& Manning (1998), smear yang terjadi sepanjang jalur migrasi RNA tersebut juga menunjukkan degradasi akibat kontaminasi RNase selama proses isolasi.
Berdasarkan uji kualitatif RNA yang didasarkan pada elektroforegram yang memvisualisasi pita ganda $18 \mathrm{~S}$ rRNA dan $28 \mathrm{~S}$ rRNA, teknik isolasi RNA berbasis kit komersial menunjukkan kualitas RNA terbaik, dan mengindikasikan keutuhan RNA total yang terisolasi (tidak terdegradasi dan tidak adanya kontaminasi protein dan polisakarida).

\section{KESIMPULAN}

Berdasarkan hasil penelitian dapat disimpulkan bahwa, RNA total hasil isolasi protokol kit komersial \#2 berbasis buffer RAP yang mengandung guanidin hidroklorida memiliki kuantitas dan kualitas yang paling tinggi dibandingkan RNA total hasil isolasi protokol kit komersial \#1 berbasis buffer RLT yang mengandung guanidin thiosianat ataupun protokol manual CTAB modifikasi. Profil hasil uji kuantitatif RNA total daun dan akar kelapa sawit yang didapatkan melalui protokol kit komersial \#2 secara berurutan menunjukkan konsentrasi sebesar 338 ng/ $\mu \mathrm{l}$ dan $184,4 \mathrm{ng} / \mu \mathrm{l}$; rasio $\mathrm{A}_{260} / \mathrm{A}_{280} \mathrm{RNA}$ total sebesar 2,13 dan 2,18; serta rasio $\mathrm{A}_{260} / \mathrm{A}_{230}$ sebesar 2,09 dan 2,20.

\section{UCAPAN TERIMAKASIH}

Penulis mengucapkan terima kasih kepada Badan Pengelola Dana Perkebunan Kelapa Sawit (BPDPKS) yang telah 
mendanai penelitian ini (Grant Riset No.

PRJ-31/DPKS/2018).

\section{KONTRIBUTOR PENULIS}

Riza merupakan pemilik gagasan riset serta mendesain eksperimen di dalam penelitian ini. Dini dan Restu menulis manuskrip penelitian. Dini dan Riza melakukan pengambilan sampel bibit kelapa sawit. Dini dan Irfan mendesain metode yang digunakan dalam penelitian ini. Sapto mengarahkan Restu selama kegiatan penelitian serta memberikan kritik dan saran dalam pengembangan manuskrip. Indra dan Dadang mempersiapkan sampel bahan tanam dalam area pembibitan terkontrol.

\section{DAFTAR PUSTAKA}

Bryant, S., and D. L. Manning. 1998. Isolation of messenger RNA. Methods Mol Biol., 86: 61-64.

Chang, Puryear, and Cairney. 1993. A Simple and Efficeint Method for Isolating RNA From Pine Trees. Plant Molekular Biology Reporter, 11(2): 113-116.

Farrell, R. E. 2005. RNA Methodologies: A Laboratory Guide for Isolation and Characterization. 3rd ed. Elsevier Academic Press. Burlington.

Gallagher, S. R. 1989. Quantitation of DNA and RNA with absorption and fluorescence spectroscopy. In Ausubel, F. A., Brent, R., Kingston, R. E., Moore, D. D., Seidman, J. G., Smith, J. A., and K. Struhl. Current Protocols in Molecular Biology. John Wiley and Sons. New York.
Gasic, K., A. Hernandez, and S. S. Korban 2004. RNA Extraction from Different Apple Tissues Rich in Polyphenols and Polysaccharides for cDNA library construction. Plant Mol. Biol. Rep., 22: 437 - 438.

Iandolino, A. B., F. G. DaSilva, H. Lim, H. Choi, L. E. Williams, D. R. Cook. 2004. High quality RNA, cDNA, and derived EST libraries from Grapevine (Vitis vinifera L.). Plant Mol. Biol. Rep., 22: 269-278.

Liu, W., B. Wang, C. Duan, C., and B. Li. 2005. A Method for Isolating Functional RNA Callus of Dendrobium candidum Contented Rich Polysaccharides. Colloid. Surface B., 4: 259-262.

Macherey-Nagel. 2006. Total RNA Purification from Plant. MachereyNagel. Germany.

Martiansyah, I., D. M. Amanah, and R.A. Putranto. 2018. Semi-quantitative RT-PCR Analysis of Transcripts Encoding Protease Inhibitor in Hevea brasiliensis Muell. Arg latex. Proceeding of International Biotechnology Conference on Estate Crops 18-20 October 2017, Jakarta, Indonesia. [IOP Conf. Series: Earth and Environmental Science 183]. IOPScience Publishing

Qiagen. 2006. RNeasy ${ }^{\circledR}$ mini handbook. 4th ed. Qiagen. Texas.

Rapley, R. and J.Heptinstall. 1998. UV Spectrophotometric Analysis of Ribonucleic Acids. In: Rapley, R., Manning, D. L. (Eds.). 1998. Methods in Molecular Biology. Vol. 86. RNA: Isolation and Characterization Protocols. Humana Press Inc. Totowa.

Sambrook, J., E. F. Fritsch and T. Maniatis. 1989. Molecular Cloning: A Laboratory Manual, 2nd edn. Cold Spring Harbor Laboratory Press. New York. 
Suehiro, N., K. Matsuda, S. Okuda and T. Natsuaki. 2005. A Simplifed Method for Obtaining Plant Viral RNA for RT-PCR. J. Virol. Methods., 125(1): 67-73.

Tattersal, E.A.R., A. Ergul, F. Alkayal, L. Deluc, J. C. Cushman, and G. R. Cramer. 2005. Comparison of Methods for Isolating High Quality RNA from Leaves of Grapevine. Amj Enol Viticult., 56: 400-406.

Teare, J. M., R. Islam, R. Flanagan, S. Gallagher, M. G. Davies, and C. Grabau. 1997. Measurement of Nucleic Acid Concentration Using the DyNa QuantTM and the GenequantTM. BioTechniques, 22(6): 1170-1171.

Wang, X. C., W. M. Tain, Y. X. Li, Y. X. 2008. Development of an efficient protocol of RNA isolation from recalcitrant tree tissues. Mol. Biotechnol., 38: 57-64.

Xiao, Y., Y. Yaodong, C. Hongxing, F. Haikuo, M. Zilong, L. Xintao, S. M. Annaliese, X. Zhihui, and H. Xi. 2012. Efficient Isolation of High Quality RNA from Tropical Palms for RNA-seq Analysis. Plant Omics Journal, 5(6): 584-589. 